\title{
Na,K-ATPase in Diabetic Rat Small Intestine Changes at Protein and mRNA Levels and Role of Glucagon
}

\author{
Kassem Barada, Charles Okolo, Michael Field, and Nadim Cortas \\ Departments of Medicine and of Physiology and Cellular Biophysics, College of Physicians and Surgeons, \\ Columbia University, New York 10032
}

\begin{abstract}
$\mathrm{Na}, \mathrm{K}$-ATPase activity and isoform expression were measured in rat small intestinal mucosa taken from both normal and streptozocin-treated diabetic rats. Enzyme activity and abundance was 1.7-2.3-fold higher in rats diabetic for 2 wk than in controls. This was associated with 1.4-1.7-fold increases in small intestinal protein and DNA content. Ouabain inhibition curves of $\mathrm{Na}, \mathrm{K}$-ATPase were monophasic with $\mathrm{K}_{\mathrm{p}} \mathrm{S}$ of $2.6 \pm 1.4$ $\times 10^{-4}$ and $2.0 \pm 1.2 \times 10^{-4} \mathrm{M}$ for control and diabetic rats, respectively (NS). Northern blot analysis revealed a 2.5 -fold increase in $\mathrm{mRNA}_{\alpha 1}$ and a 3.4-fold increase in $\mathrm{mRNA}_{\beta 1}$ in diabetic rats relative to controls. Two thirds of this increase occurred within $24 \mathrm{~h}$ after injection of streptozocin. Immunoblots of intestinal enzyme preparations from diabetic and control rats indicated the presence of $\alpha 1$ and $\beta 1$ subunits but not of $\alpha 2$ or $\alpha 3$. Administration of glucagon $(80 \mu \mathrm{g} / \mathrm{kg})$ to normal rats daily for 14-16 d increased mRNA $\alpha 1$ 3.1-fold but did not increase mRNA $A_{\beta 1}$ or enzyme activity. In experimental diabetes, $\alpha 1$ and $\beta 1$ isoforms of $\mathrm{Na}, \mathrm{K}$-ATPase are coordinately upregulated at both protein and mRNA levels, an effect which appears to be partially mediated by the associated hyperglucagonemia. ( $J$. Clin. Invest. 1994. 93:2725-2731.) Key words: $\alpha 1$ and $\beta 1$ isoforms $\bullet \mathrm{Na}, \mathrm{K}-\mathrm{ATPase} \cdot$ streptozocin $\bullet$ hypertrophy $\bullet$ small intestine
\end{abstract}

\section{Introduction}

$\mathrm{Na}, \mathrm{K}-\mathrm{ATPase}$ consists of a catalytic $\alpha$ subunit (111.7-112.6 $\mathrm{kD}$ ) and a glycosylated $\beta$ subunit (32-34 $\mathrm{kD}$, core protein). Three isoforms of the $\alpha$ subunit $(\alpha 1, \alpha 2$, and $\alpha 3)$ have been identified $(1,2)$. Their genes are located on different chromosomes and are expressed in a cell and tissue-specific manner (3, 4): $\alpha 1$ has been identified in virtually all tissues, $\alpha 2$ in the brain, heart, and skeletal muscle, and $\alpha 3$ in brain, heart, ciliary epithelium, and leukocytes $(3,5,6)$. Rat small intestine has recently been shown to express only the $\alpha 1$ isoform $(7,8)$, as had previously been shown for rat kidney (2). The mRNA levels for $\alpha 1$ and $\beta 1$ in the small intestine are considerably lower at birth than in adult rats and are increased by glucocorticoids (8). Similar results were obtained for rat colon (10). Four isoforms of the $\beta$ subunit have also been described in

Address all correspondence to Nadim Cortas, M.D., Columbia-Presbyterian Medical Center, P\&S 10-508, 630 West 168th St., New York, NY, 10032.

Received for publication 4 August 1992 and in revised form 18 February 1994.

J. Clin. Invest.

(c) The American Society for Clinical Investigation, Inc.

0021-9738/94/06/2725/07 \$2.00

Volume 93, June 1994, 2725-2731 various tissues $(2,3,5,9,11-15)$. The $\beta$ subunit contributes to localization of newly synthesized $\alpha$ subunit molecules and also protects it from hydrolytic breakdown $(14,15)$.

In rats with experimental or spontaneous diabetes, maximal Na,K-ATPase activity has been reported to be decreased in heart, retina, peripheral nerve, kidney glomeruli, and skeletal muscle ( 16-20) but to be increased in kidney tubules and intestines $(21,22)$. Experimental diabetes in rats also results in increased intestinal length, perimeter, wet and dry weight, villus height, and crypt depth (23-26). There are also increases in Na-dependent sugar, amino acid, and bile acid absorption in the ileum $(25,27-32)$, and in the number of $\mathrm{Na}$-dependent glucose carriers in ileal brush border membranes (32).

In this study of rat small intestinal mucosa, we have examined the expression of specific isoforms of $\mathrm{Na}, \mathrm{K}-\mathrm{ATPase}$ at both protein and mRNA levels and have explored the changes which occur in experimental diabetes and with administration of glucagon.

\section{Methods}

Animal preparation. Male Sprague Dawley rats were obtained from Charles River Labs (Wilmington, MA). Diabetic and age-matched control rats were housed in a light-cycled animal care facility and given ad lib access to water and regular chow. Diabetes was induced by an intraperitoneal injection of $75 \mathrm{mg} / \mathrm{kg}$ streptozocin. This dose resulted in a serum glucose level of $>300 \mathrm{mg} / \mathrm{dl}$ in $80 \%$ of rats within $24 \mathrm{~h}$ of injection; the remaining $20 \%$ were not used in this study. One group of diabetic rats was treated for $2-3$ wk beginning $24 \mathrm{~h}$ after the streptozocin injection with a daily subcutaneous injection (2-8 U) of neutral protamine hagedorn (NPH) insulin. This dose was adjusted to maintain the blood sugar $<130 \mathrm{mg} / \mathrm{dl}$. One group of normal rats was treated daily for $14-18 \mathrm{~d}$ with $80 \mu \mathrm{g} / \mathrm{kg}$ glucagon i.p. every $6 \mathrm{~h}$.

Rats were sacrificed by decapitation after mild $\mathrm{CO}_{2}$ narcosis. The small intestines were removed from the ligament of Treitz to the ileocecal junction, flushed with ice-cold $2 \mathrm{M} \mathrm{NaCl}$ and cut along the anti-mesenteric border. Small intestinal mucosae of diabetic and age matched control rats were then scraped into ice cold $2 \mathrm{M} \mathrm{NaCl}$, washed three times with $50 \mathrm{mM}$ tris $5 \mathrm{mM}$ EDTA, pH 7.2, and two times with 50 $\mathrm{mM}$ Tris $1 \mathrm{mM}$ EDTA, $\mathrm{pH} 7.2$, and homogenized at $4^{\circ} \mathrm{C}$ in $250 \mathrm{mM}$ sucrose, $30 \mathrm{mM}$ histidine, and $1 \mathrm{mM}$ EGTA buffer, $\mathrm{pH}$ 7.2. The use of hypertonic followed by hypotonic salt solutions was previously shown to loosen the mucocalyx and remove mucus from toad bladder epithelium, rendering $\mathrm{Na}, \mathrm{K}-\mathrm{ATPase}$ measurement far more accurate (33). Microsomal membranes were prepared as described by Cortas et al. (34). In some experiments sodium deoxycholate was added to the mucosal homogenate to a final concentration of $0.1 \%(0.48 \pm 0.06 \mathrm{mg}$ $\mathrm{DOC} / \mathrm{mg}$ protein ).

$\mathrm{Na}, \mathrm{K}$-ATPase assays. Assays were done at $37^{\circ} \mathrm{C}$ in the presence of $130 \mathrm{mM} \mathrm{NaCl}, 20 \mathrm{mM} \mathrm{KCl}, 5 \mathrm{mM} \mathrm{MgCl}_{2}, 3 \mathrm{mM} \mathrm{NaN}_{3}, 3 \mathrm{mM}$ ATP, and $30 \mathrm{mM}$ Tris, pH 7.2, as previously described (33). After equalization of the ouabain concentration in all tubes, the amount of phosphate released was measured by a modification of the method of Baginski and Zak (35); $2 \%$ ammonium molybdate was added instead of $1 \%$ followed within $10 \mathrm{~s}$ by $2 \%$ arsenite $-4 \%$ citrate- $2 \%$ glacial acetic acid. Na,K-ATPase activity was expressed as $\mu$ moles $P_{i} / m g$ protein $/ h(1 \mathrm{U})$. Assays were performed in the absence of detergent and/or in the pres- 
ence of $0.1-0.4 \mathrm{mg}$ sodium dodecyl sulphate (SDS) or $1 \mathrm{mg}$ sodium deoxycholate (DOC) per milligram of protein.

For ouabain inhibition curves, total homogenate or microsomal membranes were incubated for $3 \mathrm{~h}$ in the presence of varying concentrations of ouabain and $0.1-0.2 \mathrm{mg} \mathrm{SDS} / \mathrm{mg}$ protein, required to stabilize the enzyme preparations. Omission of the detergent resulted in loss of up to $70 \%$ of Na,K-ATPase activity in $3 \mathrm{~h}$ whether or not antiproteases were added.

Alkaline phosphatase was assayed in the presence of $100 \mathrm{mM}$ tris, 5 $\mathrm{mM} \mathrm{MgCl}$ and $0.1 \mathrm{mM} \mathrm{ZnCl}_{2}, \mathrm{pH} \mathrm{10.5}$, as previously described (36).

DNA was determined on perchloric acid extracts of total homogenate as previously described $(37,38)$. RNA was measured as in Maniatis et al. (39) and protein by the method of Lowry et al. (40).

Ouabain-stimulated phosphorylation of Na,K-ATPase by orthophosphate ("back door phosphorylation"). To quantitate the number of Na pump molecules, Na,K-ATPase was phosphorylated with orthophosphate (back door phosphorylation) as previously described (41, 42). Briefly, SDS-treated microsomal membranes were incubated at room temperature for $30 \mathrm{~min}$ in the presence of various concentrations of phosphate $(10-200 \mu \mathrm{M})$, SDS $(0.1-0.2 \mathrm{mg} / \mathrm{mg}$ protein) with or without $4 \mathrm{mM}$ ouabain. 5-20 $\mu \mathrm{C}_{\mathrm{i}}$ of carrier-free ${ }^{32} \mathrm{P}$-orthophosphate was then added (to reduce the presence of pyrophosphates and background radioactivity, the ${ }^{32} \mathrm{P}$-orthophosphate was preincubated with bovine kidney microsomes at $37^{\circ} \mathrm{C}$ for $30 \mathrm{~min}$ followed by filtration through a $0.22-\mu \mathrm{M}$ filter and boiling for $3 \mathrm{~min}$ ). The reaction was quenched 30 min later with $10 \% \mathrm{BSA}$ and $20 \% \mathrm{TCA}$ in $0.1 \mathrm{mM} \mathrm{H}_{3} \mathrm{PO}_{4}$. The 12,000-g TCA pellets were washed with the same solution 3-5 times, dissolved in $300 \mu \mathrm{l}$ of $0.1 \mathrm{~N} \mathrm{NaOH}$ and $10 \%$ SDS, transferred to a specific volume of Ultima Gold scintillant fluid and counted in a Beckman scintillation counter (Beckman Instruments, Inc., Fullerton, $\mathrm{CA})$. The ${ }^{32} \mathrm{P}$ bound to boiled microsomes was subtracted as background radioactivity. Ouabain-stimulated binding of phosphate (specific to $\mathrm{Na}, \mathrm{K}-\mathrm{ATPase}$ ) represented the difference between binding in the presence of ouabain and in its absence. 1 mole of $P_{i}$ in this assay binds to 1 mole of Na,K-ATPase. After subtracting background radioactivity, $60-85 \%$ of the signal is ouabain stimulated. Pump abundance, defined as the concentration of pumps per milligram of protein, was calculated and expressed in nanomoles of $\mathrm{Na}, \mathrm{K}-\mathrm{ATPase}$ per $\mathrm{mg}$ protein.

Immunoblot analysis. Partially purified enzyme was prepared according to the method of Jorgenson (43) and immunoblotted as described in Cortas et al. (34). The blots were probed with monoclonal antibodies to $\alpha 1$ (McK1), $\alpha 2$ (McB2), (provided by K. Sweadner, Harvard University, Boston, MA) and monospecific antibodies to $\alpha 3$, $\beta 1$, and $\beta 2$ obtained from upstate Biotechnology, Inc. (Lake Placid, NY). The bands were visualized either by the reduction of 5-bromo-4chloro-3-indolyl phosphate (Sigma Chemical Co., St. Louis, MO) by anti-7 mouse IgG bound alkaline phosphatase, or by labeling the antibody with radioiodinated strepavidin $\left({ }^{125} \mathrm{I}, 10^{6} \mathrm{cpm}\right)$ followed by autoradiography.

Northern blot analysis. Small intestinal mucosa was scraped and immediately frozen in liquid nitrogen. Total cellular RNA was prepared by the methods of Chirgwin et al. (44). Equal amounts of total RNA extracted from control and diabetic rats (20 $\mu \mathrm{g}$ per lane) were fractionated in a $1 \%$ agarose-6\% formaldehyde $1 \times$ MOPS gel, blotted on nitrocellulose, and probed with cDNA for $\alpha 1, \alpha 2, \alpha 3, \beta 1$, and $\beta 2$ labeled with ${ }^{32} \mathrm{P}$ by nick translation as per Russo et al. (45). Autoradiograms were quantitated by densitometry.

Statistical analysis. Curve fitting and statistical analyses were performed by BMDPAR, a derivative-free nonlinear regression software package developed at the University of California (Los Angeles, CA) and converted for use on Dec Vax-11 by Management Science Associates (Pittsburgh, PA).

\section{Results}

Mucosal mass, protein, and DNA. 64 of 76 rats injected with streptozocin had blood glucoses above $300 \mathrm{mg} / \mathrm{dl}$ (compared to $103 \pm 4 \mathrm{mg} / \mathrm{dl}$ in vehicle-treated controls) and were used for this study. Table I shows that, after 6-8 wk of diabetes, the mean final body weight $\left(W_{f}\right)$ of the streptozocin-treated rats (D3) had decreased by an average of $33 \%$ while that of agematched controls (C3) had increased by $14 \%$. In contrast, total protein and DNA contents in the small intestines of diabetic rats were 1.26-1.47 times greater than in controls (Table I). The length and mucosal wet weight of the small intestine also increased; at the end of $2 \mathrm{wk}$, lengths were $123 \pm 1$ and $148 \pm 1$ $\mathrm{cm}$ and mucosal wet weights were $4.9 \pm 0.5$ and $7.0 \pm 0.1 \mathrm{~g}$, in control and diabetic rats respectively $(P<.05$ for both differences). Results at 6-8 wk were similar. Insulin treatment of the streptozocin-treated rats prevented all these changes (Table I). There was no difference in the protein/DNA ratio between control, diabetic and insulin-treated diabetic rats.

$\mathrm{Na}, \mathrm{K}-\mathrm{ATP}$ ase activity. $\mathrm{Na}, \mathrm{K}-\mathrm{ATPase}$ activity in intestinal mucosal homogenates increased 1.7-2.3-fold within 2 wk of the onset of diabetes and remained constant thereafter (Table II). This was true whether measured per milligram of protein or per milligram of DNA. The changes were of a comparable relative magnitude in detergent-treated and in nondetergenttreated homogenates. Results were similar for Na,K-ATPase activity measured in microsomal membranes (Table III). The time course for this increase is shown in Fig. 1. The first statistically significant increase in enzyme activity was seen at $6 \mathrm{~d}$ after streptozocin injection. Mg-ATPase and alkaline phosphatase activities in homogenates of control and diabetic rats did not differ significantly (Table III).

$\mathrm{NPH}$ insulin (2-8 $\mathrm{U}$ ) administered daily for 2-3 wk to rats beginning $24 \mathrm{~h}$ after streptozocin injection, maintained the blood sugar below $130 \mathrm{mg} / \mathrm{dl}$ for at least two thirds of the study period and prevented the increase in $\mathrm{Na}, \mathrm{K}-\mathrm{ATPase}$ activity otherwise seen (Table II).

To determine whether the increase in $\mathrm{Na}, \mathrm{K}$-ATPase activity seen in diabetes resulted from an increase in pump abundance or from an increase in pump turnover number, the concentration of $\mathrm{Na} / \mathrm{K}$ pumps in intestinal microsomal mem-

Table I. Change in Animal Weight, Intestinal Mucosal Protein, and DNA Content at $1 d, 2 w k$, and 6-8 wk of Diabetes

\begin{tabular}{lcccc}
\hline & $\mathrm{W}_{\mathrm{i}}$ & $\mathrm{W}_{\mathrm{f}}$ & Protein & $\mathrm{DNA}$ \\
\hline & $g$ & $g$ & $m g$ & $m g$ \\
$\mathrm{C} 1(n=3)$ & $378.3 \pm 48.2$ & $383.5 \pm 41.1$ & $150.5 \pm 457$ & $7.9 \pm 1.0$ \\
$\mathrm{C} 2(n=5)$ & $364.4 \pm 32.8$ & $412.4 \pm 34.7^{*}$ & $255.0 \pm 53.0$ & $9.6 \pm 1.5$ \\
$\mathrm{C} 3(n=10)$ & $432.8 \pm 16.0$ & $491.8 \pm 10.5^{*}$ & $249.5 \pm 38.6$ & $7.5 \pm 1.3$ \\
$\mathrm{D} 1(n=3)$ & $373.7 \pm 54.9$ & $344.3 \pm 56.7$ & $209.3 \pm 82.0$ & $7.8 \pm 0.1$ \\
$\mathrm{D} 2(n=5)$ & $365.4 \pm 31.7$ & $276.6 \pm 22.7^{*}$ & $427.4 \pm 61.4^{\ddagger}$ & $14.3 \pm 2.3^{\ddagger}$ \\
$\mathrm{D} 3(n=10)$ & $421.3 \pm 20.6$ & $280.0 \pm 12.6^{*}$ & $364.0 \pm 57.7^{\ddagger}$ & $10.4 \pm 1.5^{\ddagger}$ \\
$\mathrm{I} 2(n=3)$ & $388.0 \pm 10.0$ & $431.0 \pm 23.0$ & $193.3 \pm 36.8$ & $6.5 \pm 1.6$
\end{tabular}

Control $(C)$, diabetic $(D)$, and insulin-treated $(I)$ rats were weighed at the time of streptozocin/vehicle injection $\left(W_{i}\right)$ and just before sacrifice $\left(W_{f}\right)$ at $1 \mathrm{~d}(C I$ and $D 1), 2 \mathrm{wk}(C 2, D 2$, and $I 2)$, and 6-8 wk ( $C 3$ and D3). Intestines were removed from ligament of Treitz to the ileocecal valve, mucosa scraped and total mucosal protein and DNA measured. Values are means \pm SEM. ${ }^{*}$ Different from corresponding $W_{i}$ values $(P<0.05)$. ${ }^{\ddagger}$ Different from corresponding control values $(P$ $<0.01)$. 
Table II. Na,K-ATPase, Mg,ATPase, and Alkaline Phosphatase Activities in Intestinal Mucosal Homogenate of Control and STZ-treated Diabetic Rats

\begin{tabular}{|c|c|c|c|c|c|}
\hline & \multicolumn{3}{|c|}{$\mathrm{Na}, \mathrm{K}-\mathrm{ATPase}$ activity } & \multirow[b]{2}{*}{ Mg,ATPase } & \multirow[b]{2}{*}{ Alk. phos. } \\
\hline & $(-)$ SDS & (+) SDS & (+) SDS & & \\
\hline & \multicolumn{2}{|c|}{$\mu M P_{i} / h / m g$ protein } & per mg DNA & \multicolumn{2}{|c|}{$\mu M P_{i} / h / m g$ protein } \\
\hline $\mathrm{Cl}$ & $7.0 \pm 0.1$ & - & - & $8.4 \pm 0.6$ & - \\
\hline $\mathrm{C} 2$ & $4.7 \pm 0.5$ & $9.0 \pm 0.5$ & - & $7.5 \pm 1.4$ & - \\
\hline C3 & $4.4 \pm 0.7$ & $9.1 \pm 1.7$ & $134.7 \pm 15.5$ & $7.0 \pm 0.7$ & $33.4 \pm 6.1$ \\
\hline D1 & $8.9 \pm 2.1$ & - & - & $8.5 \pm 1.6$ & - \\
\hline D2 & $10.7 \pm 0.6^{*}$ & $15.4 \pm 0.9^{*}$ & - & $8.8 \pm 0.8$ & - \\
\hline D3 & $10.0 \pm 0.3^{*}$ & $16.3 \pm 2.3^{*}$ & $353.0 \pm 35.9^{*}$ & $6.7 \pm 0.7$ & $41.5 \pm 12.0$ \\
\hline $\mathrm{I} 2$ & $6.6 \pm 1.7$ & - & $181.9 \pm 49.4$ & - & - \\
\hline
\end{tabular}

Maximal Na,K-ATPase, Mg-ATPase, and Alkaline phosphatase activities assayed in intestinal mucosal homogenate from control $(C)$, diabetic $(D)$, and insulin-treated $(I)$ diabetic rats sacrificed at day 1 $(C 1$ and $D 1), 2$ wk $(C 2, D 2$, and $I 2)$ and 6-8 wk (C3 and $D 3)$ after onset of diabetes. Na,K-ATPase was measured in the presence and/or absence of detergent (see Methods). All values are means \pm SEM of activities. ${ }^{*}$ Greater than control values $(P<0.01)$.

branes was measured by "back door" phosphorylation. As shown in Table III, diabetes caused a 2.5 -fold increase in pump abundance, almost completely accounting for the increase in $\mathrm{Na}$, K-ATPase activity. $\mathrm{Na} / \mathrm{K}$ pump turnover did not change significantly.

To determine whether diabetes alters the affinity of small intestinal $\mathrm{Na}, \mathrm{K}-\mathrm{ATPase}$ for $\mathrm{Na}^{+}$, mucosal homogenate enzyme activity was determined in 15 -min assays at varying concentrations of $\mathrm{Na}^{+}$in the absence of detergent. There was no difference in the determined $\mathrm{Kms}$ for $\mathrm{Na}+(14.9 \pm 1.2 \mathrm{mM}$ in control rats $[n=4]$ vs $13.1 \pm 1.8 \mathrm{mM}$ in diabetic rats $[n=4])$.

Alpha isoforms of Na,K-ATPase are known to differ in their sensitivity to inhibition by ouabain (2). To determine if enzyme molecules with more than one sensitivity to inhibition by ouabain are expressed in normal or diabetic small intestinal mucosa, Na,K-ATPase activities in homogenates and microsomal membranes from control and diabetic rats were measured at different concentrations of ouabain. As shown in Fig.

Table III. Na,K-ATPase Activity, Na/K Pump Abundance and Turnover Rate in Mucosal Microsomal Membranes of Control (C3) and Diabetic (D3) Rats (6-8 wk)

\begin{tabular}{|c|c|c|c|c|c|}
\hline & \multicolumn{2}{|c|}{ Na,K-ATPase activity } & \multirow{2}{*}{$\begin{array}{l}\mathrm{Na} / \mathrm{K} \text { pump } \\
\text { abundance }\end{array}$} & \multirow{2}{*}{$\begin{array}{c}\mathrm{Na} / \mathrm{K} \text { pump } \\
\text { turnover }\end{array}$} & \multirow{2}{*}{$\begin{array}{c}\text { Mg,ATPase } \\
(+) \text { DET }\end{array}$} \\
\hline & $(-)$ DET & $(+) \mathrm{DET})$ & & & \\
\hline $\mathrm{C} 3$ & $14.1 \pm 1.6$ & $30.6 \pm 5.1$ & $49.3 \pm 19.5$ & $11.9 \pm 3.1$ & $23.5 \pm 2.5$ \\
\hline D3 & $\begin{array}{c}23.7 \pm 2.1 \\
P<0.02 \\
(n=5)\end{array}$ & $\begin{array}{c}68.0 \pm 12.1 \\
P<0.02 \\
(n=9)\end{array}$ & $\begin{array}{c}125.0 \pm 31.0 \\
P<0.05 \\
(n=4)\end{array}$ & $\begin{array}{c}9.2 \pm 1.9 \\
(\mathrm{NS}) \\
(n=4)\end{array}$ & $\begin{array}{c}24.3 \pm 2.6 \\
(\mathrm{NS}) \\
(n=9)\end{array}$ \\
\hline
\end{tabular}

Values are means \pm SEM. ATPase activity was expressed as $\mu$ moles $P_{\mathrm{i}} / \mathrm{mg}$ protein/h. $\mathrm{Na} / \mathrm{K}$ pump abundance was expressed as picomoles of enzyme $/ \mathrm{mg}$ protein and turnover in nanomoles $\mathrm{P}_{\mathrm{i}} / \mathrm{min}$. DET, detergent (see Methods).

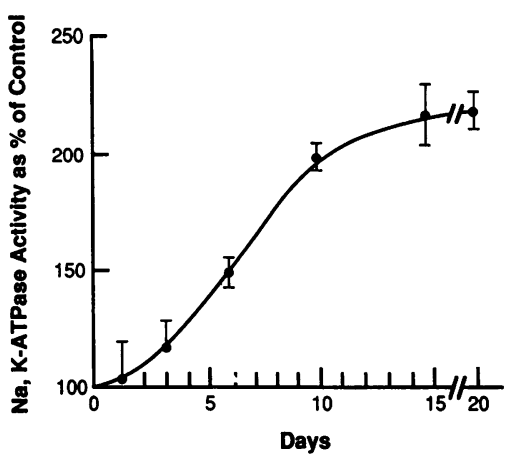

Figure 1. Time course of change in small intestinal Na,K-ATPase activity with diabetes. Enzyme activity was measured in intestinal mucosal homogenates obtained from rats with different durations of diabetes and agematched controls. Assays were performed in the presence of SDS.

The proportional (\%) increase in activity in diabetes is shown as a function of duration. ( $P$ $<0.01$ as of day 6 )

2, monophasic ouabain inhibition curves were obtained for rat mucosal microsomal membranes with equivalent apparent $\mathrm{K}_{\mathrm{i}} \mathrm{s}$ of $2.6 \pm 1.4 \times 10^{-4} \mathrm{M}$ and $2.0 \pm 1.2 \times 10^{-4} \mathrm{M}$ (NS) for control and diabetic rats respectively. Comparable curves and $\mathrm{K}_{\mathrm{i}} \mathrm{s}$ were obtained with mucosal homogenates (data not shown).

Immunoblots. Immunoblots with anti- $\alpha 1, \alpha 2$, and $\alpha 3$ monospecific antibodies were initially performed on protein from mucosal homogenates and microsomal membranes from diabetic and control rats. The signal to noise ratio was too low for interpretation. We therefore partially purified the $\mathrm{Na}, \mathrm{K}-\mathrm{ATP}$ ase in microsomal membranes by SDS treatment followed by centrifugation through glycerol gradient (34). These preparations showed sevenfold $(120 \pm 19 \mu \mathrm{m})$ and 10 fold $(94 \pm 9.5 \mu \mathrm{m})$ increases in enzyme specific activity for diabetic and control rats, respectively. SDS-PAGE analyses (34, 46) of these preparations demonstrated enrichment of the 92.5-kD band representing the $\alpha$ subunit(s) of $\mathrm{Na}, \mathrm{K}-\mathrm{ATPase}$, as compared with untreated microsomal membranes (Fig. 3). The identity of this band was confirmed by immunoblot analysis. As shown in Fig. 4, $\alpha 1$ but not $\alpha 2$ or $\alpha 3$ were detected, as was also $\beta 1$.

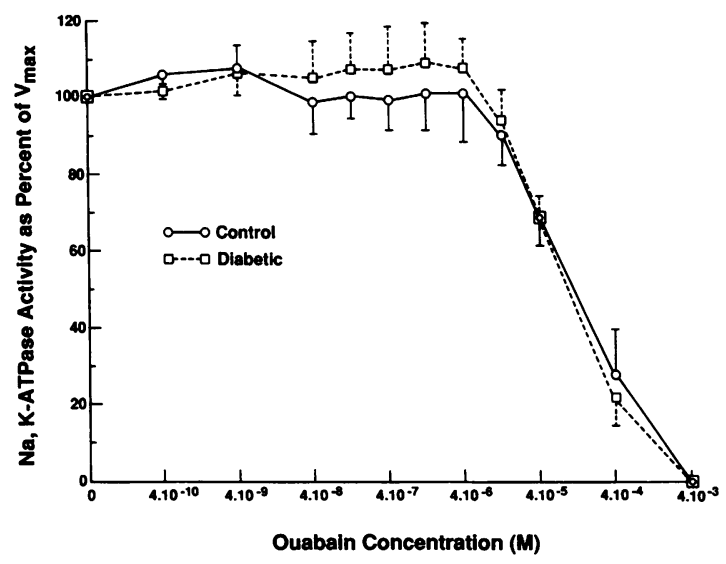

Figure 2. Na,K-ATPase activity in intestinal mucosal microsomal membranes isolated from diabetic (6-8 wk) and age-matched control rats were assayed with different concentrations of ouabain. Membranes were treated for $30 \mathrm{~min}$ with SDS ( $1 \mathrm{mg}$ protein $/ 0.3-0.5 \mathrm{mg}$ SDS), diluted 15-20X, and incubated for $3 \mathrm{~h}$ with ouabain before assay. $\mathrm{Na}, \mathrm{K}-\mathrm{ATPase}$ activities are expressed as percent of maximum, $\mathrm{V}_{\max } \cdot\left(--\mathrm{-}^{---)}\right.$) Diabetic microsomes; $(-0-)$ control microsomes. Each point is the mean \pm SEM of four experiments. 


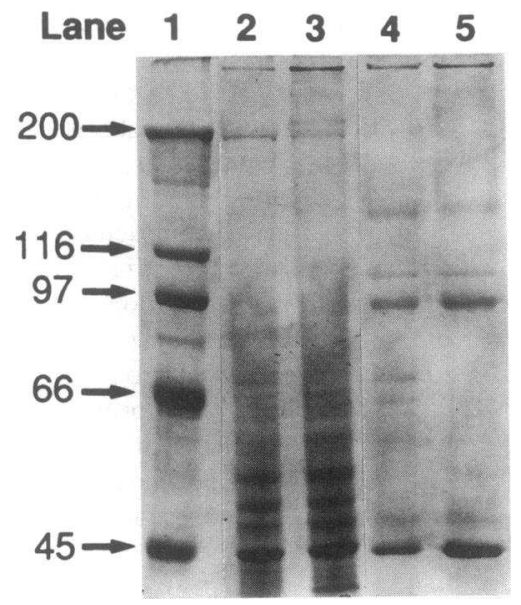

Figure 3. SDS-PAGE of partially purified $\mathrm{Na}, \mathrm{K}-\mathrm{ATPase}$ from intestinal mucosa of control and diabetic rats. The gel was stained with Coomassie blue. (Lane 1) High molecular weight standards from top to bottom (all in kD): Myosin 200, $\beta$-galactosidase 116 , phosphorylase b 92 , bovine serum albumin 66 , ovalbumin 45 . (Lane 2) $60 \mu \mathrm{g}$ of intestinal mucosal microsomal membrane protein from control rats $(\mathrm{Na}, \mathrm{K}-\mathrm{ATP}$ ase activity $=14 \mathrm{U}$ ). (Lane 3) $60 \mu \mathrm{g}$ of intestinal mucosal microsomal membrane protein from diabetic rats ( Na,K-ATPase activity = $23 \mathrm{U}$ ). (Lane 4$) 30 \mu \mathrm{g}$ of partially purified $\mathrm{Na}, \mathrm{K}-\mathrm{ATP}$ ase protein from control rat intestinal mucosa ( Na,K-ATPase activity = $105 \mathrm{U}$ ). ( Lane 5 ) $30 \mu \mathrm{g}$ of partially purified $\mathrm{Na}, \mathrm{K}-\mathrm{ATPase}$ protein from diabetic rat intestinal mucosa $(\mathrm{Na}, \mathrm{K}-\mathrm{ATPase}$ activity $=150 \mathrm{U})$.

The sensitivity of the antibody probes for $\alpha 2$ and $\alpha 3$ was checked on immunoblots containing different amounts of partially purified brain $(\alpha 1, \alpha 2$, and $\alpha 3)$, kidney $(\alpha 1)$ and intestinal mucosa $(\alpha 1) \mathrm{Na}, \mathrm{K}-\mathrm{ATPase}$ preparations. In the brain, $\alpha 1, \alpha 2$, and $\alpha 3$ are equal in abundance. The minimum amounts of $\mathrm{Na}, \mathrm{K}-\mathrm{ATPase}$ required for detection of $\alpha 1, \alpha 2$, and $\alpha 3$ in the brain and $\alpha 1$ in intestinal mucosa were equivalent and ranged from $0.035-0.045 \mathrm{U}$ of $\mathrm{Na}, \mathrm{K}-\mathrm{ATPase}$ activity. Anti- $\alpha 2$ and anti- $\alpha 3$ antibodies did not cross react with the $\alpha 1$ subunit in the kidney preparation. To avoid anomalous mobility of the bands on SDS-PAGE (34), we could maximally load $10 \mathrm{U}$ of partially purified small intestinal $\mathrm{Na}, \mathrm{K}-\mathrm{ATPase}$ for immunoblot analysis. $\alpha 1$ was clearly detected but not $\alpha 2$. Hence $\alpha 2$, if present at all, would be $<0.5 \%$ of $\alpha 1$. The same was true for $\alpha 3$.
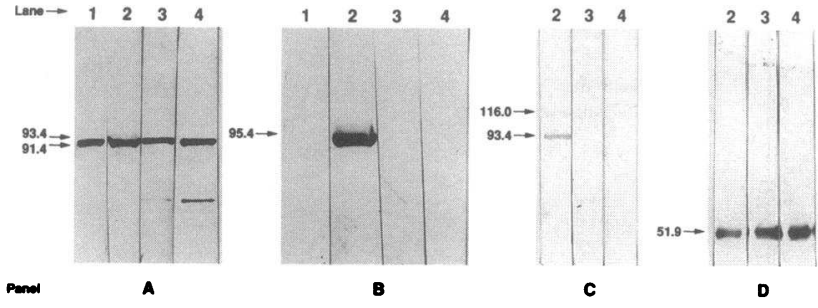

Figure 4. Partially purified Na,K-ATPase preparations from control and diabetic rat intestinal mucosa, rat brain and kidney were resolved by SDS-PAGE, electroblotted on PVDF membranes, and probed with; $(A)$ McK1, a monospecific anti- $\alpha 1$ antibody, $(B) \mathrm{McB} 2$, a monospecific anti- $\alpha 2$ antibody; $(C)$ a polyclonal anti- $\alpha 3$ antibody; $(D)$ polyclonal anti- $\beta 1$ antibody. Rat kidney medulla and brain $\mathrm{Na}, \mathrm{K}-\mathrm{ATP}$ ase preparations were used as positive controls. In all panels; lane 1, Na,K-ATPase from kidney medulla; lane 2, Na,K-ATPase from brain; lane 3, partially purified $\mathrm{Na}, \mathrm{K}-\mathrm{ATPase}$ from control intestinal mucosa; and lane 4 , partially purified $\mathrm{Na}, \mathrm{K}-\mathrm{ATPase}$ from diabetic intestinal mucosa.
Immunoblot analysis after labeling with ${ }^{125}$ I-strepavidin and autoradiography also demonstrated that the increased $\mathrm{Na}, \mathrm{K}-\mathrm{ATPase}$ activity with diabetes is associated with increased abundance of $\alpha 1$ and $\beta 1$ subunits. Enzyme abundance was measured by densitometric scanning of the autoradiograms. A constant $\mathrm{Na}, \mathrm{K}-\mathrm{ATPase}$ activity to abundance ratio was obtained for both control and diabetic preparations, indicating again similar turnover numbers.

Northern blots. To determine whether the increase in $\mathrm{Na}, \mathrm{K}-\mathrm{ATPase}$ activity and $\alpha 1$ and $\beta 1$ abundances seen with diabetes are associated with increases in mRNA encoding these subunits, Northern blots of total RNA were probed with ${ }^{32} \mathrm{P}$-labeled cDNA $\alpha 1, \alpha 2, \alpha 3$, and $\beta 1$. Quantitation of the autoradiograms by densitometry revealed 2.0- and 2.1-fold increases in $\mathrm{mRNA}_{\alpha 1}$ and $\mathrm{mRNA}_{\beta 1}$, respectively $1 \mathrm{~d}$ after the onset of diabetes $(n=3)$. Maximal changes consisting of 2.5- and 3.4-fold increases in $\mathrm{mRNA}_{\alpha 1}$ and $\mathrm{mRNA}_{\beta 1}$, respectively, were achieved within 2 wk (Figs. 5 and 6 ), and maintained for at least $8 \mathrm{wk} . \mathrm{mRNA}_{\alpha 2}$ and $\mathrm{mRNA}_{\alpha 3}$ were not detected.

To determine whether the increased abundance of $\mathrm{mRNA}_{\alpha 1}$ and $\mathrm{mRNA}_{\beta 1}$ seen in diabetic rat intestine was due to the associated increase in serum glucagon concentration, glucagon $(80 \mu \mathrm{g} / \mathrm{kg})$ was administered daily to normal rats for 14-18 d. Rats were then sacrificed and their small intestinal mucosal RNA was tested with the $\alpha 1$ cDNA probe. There was a 3.1-fold increase in $\mathrm{mRNA}_{\alpha 1}$ while $\mathrm{mRNA}_{\beta 1}$ remained unchanged when compared to control rats given vehicle alone (Figs. 5 and 6). Na,K-ATPase activity in intestinal homogenates however, did not change $(6.3 \pm 0.4 \mu \mathrm{m}$ and $6.2 \pm 0.7$ for glucagon-treated rats and control rats, respectively). In Figs. 5 and 6, two bands were generally detected with $\mathrm{CDNA}_{\alpha 1}$ or $\mathrm{cDNA}_{\beta 1}$ similar to those reported by Russo et al. (45). Young et al. (9) obtained four bands when they probed mRNA extracted from rat kidney or brain with $\mathrm{cDNA}_{\beta 1}$, the relative intensities of the bands differed in kidney and brain. Restriction analysis revealed identical $\mathrm{cDNA}_{\beta 1}$ in both and that the multiple mRNAs encode a single $\mathrm{Na}, \mathrm{K}-\mathrm{ATPase} \beta$ subunit protein. We further observed that the relative intensity of the various bands changes with the voltage and hence the total time the gel is run. In Fig. 6, lanes 1 and 3 as well as 5 and 6 are control mRNA probed with $\mathrm{cDNA}_{\beta 1}$, the relative intensities of the upper and lower bands are different. We therefore elected to scan all bands produced by the labeled cDNA and compare total intensities.

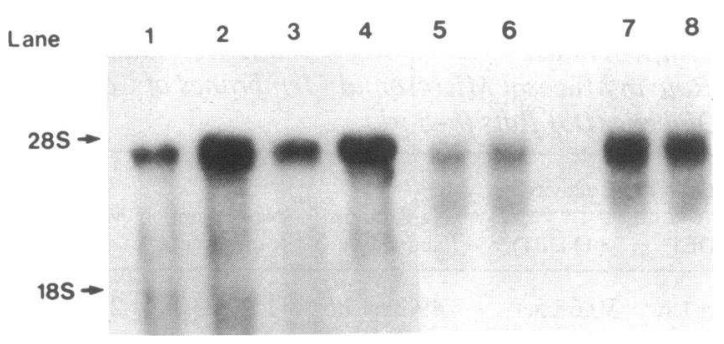

Figure 5. Detection of $\mathrm{mRNA}_{\alpha 1}$. Autoradiograms of Northern blots of total RNA extracted from small intestinal mucosa of control and diabetic rats. Equal amounts of RNA ( $20 \mu \mathrm{g})$ were fractionated in a $1 \%$ agarose gel and transferred onto nitrocellulose membranes. The blots were hybridized with ${ }^{32} \mathrm{P}$-dTTP labeled $\mathrm{cDNA}_{\alpha 1}$. Lanes 1 and 3 are from control rats; lanes 2 and 4 from diabetic rats; lanes 5 and 6 from age matched controls of glucagon-treated rats; and lanes 7 and 8 from rats treated with glucagon for 2 wk. 


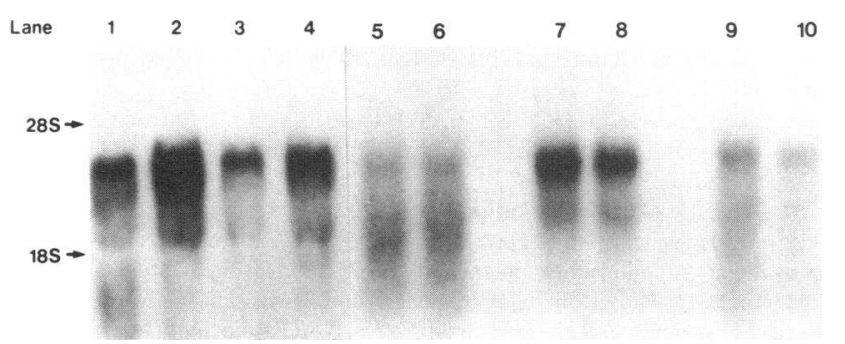

Figure 6. Detection of mRNA $\mathrm{Al}_{\boldsymbol{\beta}}$. Autoradiograms of Northern blots of total RNA extracted from small intestinal mucosa of control and diabetic rats. Equal amounts of RNA $(20 \mu \mathrm{g})$ were fractionated in a $1 \%$ agarose gel and transferred onto nitrocellulose membranes. The blots were hybridized with ${ }^{32} \mathrm{P}$-dTTP labeled $\mathrm{CDNA}_{\beta 1}$. Lanes 1 and 3 are from control rats; lanes 2 and 4 from diabetic rats; lanes 5 and 6 from age matched controls of glucagon-treated rats; lanes 7 and 8 from diabetic rats; and lanes 9 and 10 from rats treated with glucagon for 2 wk.

\section{Discussion}

Streptozocin-induced diabetes in the rat results in increases in small intestinal mucosal mass, protein and DNA contents, implying an increase in the total number of intestinal epithelial cells. These became maximal within 2 wk and remained essentially constant thereafter. These findings are in agreement with histologic studies showing significant intestinal mucosal hypertrophy and hyperplasia in rats with diabetes (23-26). This hyperplasia is also seen in renal tubules $(21,47)$ but not in a number of other organs tested.

Similarly, increases in intestinal mucosal Na,K-ATPase activity and abundance were maximal within $2 \mathrm{wk}$. This change in enzyme activity was preceded by coordinate increases in mRNA encoding the $\alpha 1$ and $\beta 1$ subunits of $\mathrm{Na}, \mathrm{K}-\mathrm{ATPase}$. The increase in enzyme activity was detectable by the third day of diabetes and became statistically significant by the sixth day. An increase in Na,K-ATPase activity with diabetes was previously reported in renal tubules but not glomeruli $(21,47)$ and in rat intestinal mucosa (22) although in neither case were its time course and transcriptional regulation determined. Hence, the two tissues, (small intestinal mucosa and renal tubule) whose mass increased with diabetes were also those in which the specific activity of $\mathrm{Na}, \mathrm{K}-\mathrm{ATPase}$ increased. The twofold increase in mRNA encoding Na,K-ATPase seen $24 \mathrm{~h}$ after streptozocin injection most likely preceded the onset of mucosal cell proliferation. Thymidine uptake studies are needed to confirm this.

In contrast to the intestinal mucosa and renal tubules, $\mathrm{Na}, \mathrm{K}-\mathrm{ATPase}$ activity decreased with diabetes in the heart (17), neural tissues $(19,20)$, and skeletal muscle (16). These decreases were seen in the absence of significant changes in tissue mass, protein and DNA contents.

Three isoforms ( $\alpha 1, \alpha 2$, and $\alpha 3)$ of the catalytic subunit of $\mathrm{Na}, \mathrm{K}-\mathrm{ATPase}$ have been detected in adult rat heart and brain but only one isoform $(\alpha 1)$ in adult rat kidney $(2,34)$; as in the latter tissue, only the $\alpha 1$ isoform, has been detected in small intestinal mucosa $(7,8)$. The present study shows this to be true for both diabetic and control small intestinal mucosa as evidenced by: ( $a$ ) monophasic ouabain inhibition curves, $(b)$ immunoblot analysis of the partially purified enzyme, and $(c)$ Northern blot analysis of total intestinal mucosal RNA. At functional, protein, and mRNA levels, therefore, evidence was obtained for the presence of $\alpha 1$ but not $\alpha 2$ or $\alpha 3$ subunits of $\mathrm{Na}, \mathrm{K}-\mathrm{ATPase}$ under both control and experimental diabetes conditions.

Streptozocin-induced diabetes in the rat is characterized by hyperglycemia, a decrease in serum insulin and an increase in serum immunoreactive glucagon concentrations $(48,49)$. It is also associated with increases in serum concentrations of mineralocorticoids and glucocorticoids, a decrease in serum concentrations of thyroid hormones, an increase in serum $\left[\mathrm{K}^{+}\right]$, and a decrease in total body $\mathrm{K}^{+}(50,51)$. The differential regulation of $\mathrm{Na}, \mathrm{K}$-ATPase isoform(s) abundance in various tissues (myoneural vs epithelial) with diabetes is inconsistent with the known effects on $\mathrm{Na}, \mathrm{K}-\mathrm{ATPase}$, of insulin, thyroid hormone, aldosterone and serum $\left[\mathrm{K}^{+}\right]$. High concentrations of insulin increased $\mathrm{Na}, \mathrm{K}-\mathrm{ATPase}$ and/or $\mathrm{Na}^{+}$transport in tissues studied ( 52). Hypothyroidism decreases $\mathrm{Na}, \mathrm{K}$-ATPase in the gut (53). Mineralocorticoid receptors appear to be present in the colon but not in the small intestine $(54,55)$. The increased $\mathrm{Na}, \mathrm{K}$-ATPase activity occurring in the proximal convoluted tubules (PCT) and medullary thick ascending limb of Henle's loop (MAL) with diabetes was not prevented by adrenalectomy although that occurring in the cortical convoluted tubules (CCT) was prevented (50). In rat small intestine, a very high dose of hydrocortisone increased $\mathrm{Na}, \mathrm{K}-\mathrm{ATPase}$ by $30 \%$, which is only a small fraction of the increase in $\mathrm{Na}, \mathrm{K}-\mathrm{ATPase}$ measured in the same study in streptozocin-induced diabetes (56). High doses of other glucocorticoids have also been shown to increase $\mathrm{Na}, \mathrm{K}$-ATPase activity in rat small intestine $(9,57,58)$. As for $\mathrm{K}^{+}$, only extreme changes incompatible with life have been shown in vitro to induce new synthesis of Na,K-ATPase (59).

Glucagon, on the other hand, was shown in the present study to cause a marked increase in mRNA $_{\alpha 1}$ but not mRNA ma1 $_{\beta 1}$. The increase in $\mathrm{mRNA}_{\alpha 1}$ was similar in magnitude to that seen with diabetes. Measurements of intestinal enzyme activity after glucagon administration revealed no increase in enzyme activity, however. The determinants that upregulate the $\beta 1$ subunit in diabetes need to be further investigated. A prior study demonstrated that the sensitivity of rat ileal transepithelial $\mathrm{Na}^{+}$ transport to inhibition by ouabain is decreased in experimental diabetes and that this effect could be mimicked by the in vitro addition of glucagon (60). The relation of those effects to the present findings is uncertain but could involve synthesis and basolateral membrane localization of new enzyme.

We are not aware of measurements of intestinal $\mathrm{Na}, \mathrm{K}-\mathrm{ATPase}$ in diabetic humans. In several other respects, however, intestinal changes in streptozocin-induced diabetes in the rat have been shown to mimic the human disease. This is true for the observed mucosal hypertrophy (61), for the appearance of autonomic neuropathy (62) for the enhancement of the absorptive processes for sugar and amino acids (63), and for increases in circulating levels of glucagon $(48,49)$.

Studies in liver epithelial cells by Koch and Leffert (64) and in 3 T3 fibroblasts by Smith and Rozengurt (65) suggest a relationship between glucagon, $\mathrm{Na}, \mathrm{K}-\mathrm{ATPase}$ and cell proliferation. Trophic hormones such as glucagon, insulin and EGF were found to produce a short term (1-2 h) effect in which $\mathrm{Na}, \mathrm{K}-\mathrm{ATPase}$ activity increases in response to enhanced sodium influx and a long term $(6-48 \mathrm{~h})$ effect involving new protein synthesis in which $\mathrm{Na}, \mathrm{K}-\mathrm{ATPase}$ activity and abundance, as well as sugar and amino acid transports, increases. These changes were associated with ouabain-inhibitable in- 
creases in DNA synthesis and cell proliferation (64-68). Increased $\mathrm{Na}, \mathrm{K}-\mathrm{ATPase} \mathrm{mRNA}_{\beta 1}$ subunit abundance preceded hepatic epithelial cell proliferation (69). A possible physiologic role of the increased $\mathrm{Na}, \mathrm{K}$-ATPase activity seen in diabetes in the small intestine, liver, and kidneys is to facilitate the also observed increases in $\mathrm{Na}^{+}$-dependent solute transport (27).

\section{Acknowledgments}

It is a pleasure to thank Dr. Kathleen Sweadner for generously providing us with the monospecific antibodies (McK1 and $\mathrm{McB} 2$ ) and Dr. Jerry Lingrel for his gift of Na,K-ATPase cDNAs for $\alpha 1, \alpha 2$, and $\alpha 3$ subunits.

This work was supported by National Institutes of Health grant DK-39105-01. Dr. Cortas is also supported by an investigatorship from the American Heart Association NYC affiliate. The Juvenile Diabetes Foundation International provided fellowship support for Kassem Barada.

\section{References}

1. Urayama, O., H. Shutt, and K. J. Sweadner. 1989. Identification of three isozyme proteins of the catalytic subunit of the Na,K-ATPase in rat brain. J. Biol. Chem. 264:8271-8280.

2. Sweadner, K. J. 1989. Isozymes of the $\mathrm{Na}^{+} / \mathrm{K}^{+}-\mathrm{ATPase}$. Biochim. Biophys. Acta. 988:185-22037.

3. Lingrel, J. B., J. Orlowski, M. M. Shull, and E. M. Price. 1990. Molecular genetics of Na,K-ATPase. Prog. Nucleic Acid. Res. Mol. Biol. 38:37-89.

4. Orlowski, J., and J. B. Lingrel. 1988. Tissue-specific and developmental regulation of rat $\mathrm{Na}, \mathrm{K}-\mathrm{ATPase}$ catalytic $\alpha$ isoform and $\beta$ subunit mRNAs. $J$. Biol. Chem. 263:19436-19442.

5. Sweadner, K. J. 1991. Overview: subunit diversity in the Na,K-ATPase. In The Sodium Pump: Structure, Mechanism, and Regulation. J. H. Kaplan, and P. De Weer, editors. The Rockefeller University Press, New York. 63-76.

6. Herrera, V. L. M., J. R. Emanuel, N. Ruiz-Opazo, R. Levenson, and B. Nadal-Ginard. 1987. Three differentially expressed $\mathrm{Na}, \mathrm{K}-\mathrm{ATP}$ ase $\alpha$ subunit isoforms: structural and functional implications. J. Cell Biol. 105:1855-1865.

7. Barada, K., C. Okolo, M. Field, and N. Cortas. 1990. Chronic Diabetes increases Na,K-ATPase Activity, $\alpha 1$ Isoform Protein, and mRNA abundance in Rat Small Intestinal Mucosa. The Sodium Pump: Recent Developments. Volume 46, Part 2. J. H. Kaplan, and P. De Weer, editors. The Rockefeller University Press, New York. 605-608.

8. Zemelman, B. V., S. W. Chui, D. E. Housman, and W. A. Walker. 1991. Developmental regulation of Na,K-ATPase mRNA expression in the rat intestine: A possible cause for increased toxigenic diarrhea in the neonate. Gastroenterology. 96:696a. (Abstr.)

9. Young, R., E. G. Shull, and J. Lingrel. 1987. Multiple mRNAs from Rat Kidney and Brain Encode a single Na,K-ATPase $\beta$ subunit Protein. J. Biol. Chem. 262:4905-4910.

10. Fuller, P. J., and K. Verity. 1990. Colonic sodium-potassium adenosine triphosphatase subunit expression: ontogeny and regulation by adrenocortical steroids. Endocrinology. 127:32-37.

11. Juanin, P., K. Richter, I. Corthesy, and K. Geering. 1990. Post translational properties of a putative $\beta 2$-Subunit of Na,K-ATPase. J. Gen. Physiol. 60-61a. (Abstr.)

12. Gloor, S., H. Antoniceck, K. J. Sweadner, S. Pagliusi, R. Frank, M. Moos, and M. Schachner. 1990. The adhesion molecule on glia (AMOG) is a homologue of the $\beta$ subunit of the Na,K-ATPase. J. Cell Biol. 110:165-174.

13. Horisberger, J. D., P. Jaunin, M. A. Reuben, L. S. Lasater, D. C. Chow, J. G. Forte, G. Sachs, B. C. Rossier, and K. Geering. 1991. The H, K-ATPase B-subunit can act as a surrogate for the B-subunit of Na,K-Pumps. J. Biol. Chem. 266:19131-19134.

14. Geering, K., T. F. Verrey, M. T. Hauptle, and B. C. Rossier. 1989. A role for the B-subunit in the expression of functional $\mathrm{Na}^{+}-\mathrm{K}^{+}-\mathrm{ATPase}$ in Xenopus oocytes. Am. J. Physiol. C851-C858.

15. Nogushi, S., K. Higashi, and M. Kawamura. 1990. A possible role of the B-subunit of $(\mathrm{Na}, \mathrm{K})$-ATPase in facilitating correct assembly of the $\alpha$-subunit into the membrane. J. Biol. Chem. 265:15991-15995.

16. Kjeldsen K., H. Braembgaard, P. Sidenins, J. S. Lasen, and A. Nogaard. 1987. Diabetes decreases $\mathrm{Na}+-\mathrm{K}+$ pump concentration in skeletal muscles, ventricular muscle, and peripheral nerves of rat. Diabetes. 36:842-848.

17. Pierce, G. N., and N. S. Dhalla. 1983. Sarcolemmal $\mathrm{Na}^{+}-\mathrm{K}^{+}-\mathrm{ATPase}$ activity in diabetic rat heart. Am. J. Physiol. 245:241-C247.
18. MacGregor, L. C., and F. M. Matschinsky. 1986. Experimental diabetes impairs the function of the retinal pigmented epithelium. Metab. Clin. Exp. 35(4 Suppl. 1):28-34.

19. Brismar, T., and A. A. F. Sima. 1981. Changes in nodal function in nerve fibers of the spontaneously diabetic BB-Wistar rat: potential clamp analysis. Acta. Physiol. Scand. 113:499-506.

20. Green, D. A., and S. A. Lattimer. 1983. Impaired rat sciatic nerve sodium potassium adenosine triphosphatase in acute streptozocin diabetes and its correction by dietary myo-inositol supplementation. J. Clin. Invest. 72:1058-1063.

21. Ku, D. D., R. B. Roberts, B. M. Sellers, and E. Meezan. 1987. Regression of renal hypertrophy and elevated renal $\mathrm{Na}^{+}, \mathrm{K}^{+}$-ATPase activity after insulin treatment in streptozocin-diabetic rats. Endocrinology. 120:2166-2173.

22. Luppa, D., and F., Muller. 1982. Increase of the $\left(\mathrm{Na}^{+}+\mathrm{K}^{+}\right)$-activated ATPase activity of basolateral plasma membranes from intestinal mucosa of diabetic rats. Acta Biologica Medica Germanica. 41:891-898.

23. Mayhew, T. M., and F. Carson. 1989. Mechanisms of adaptation in rat small intestine: regional differences in quantitative morphology during normal growth and experimental hypertrophy. J. Anat. 164:189-200.

24. Jervis, E. L., and R. J. Levin. 1966. Anatomic adaptation of the gastrointestinal tract of the rat to the hyperphagia of chronic alloxan-diabetes. Nature (Lond.). 210:391-393.

25. Fedorak, R. N., E. B. Chang, J. L. Madara, and M. Field. 1987. Intestinal adaptation to diabetes; altered Na-dependent nutrient absorption in Streptozocin-treated Chronically diabetic rats. J. Clin. Invest. 79:1571-1578.

26. Schedl, H. P., and H. Wilson. 1971. Effects of diabetes on intestinal growth and hexose transport in the rat. Am. J. Physiol. 220:1739-1745.

27. Crane, R. K. 1961. An effect of alloxan-diabetes on the active transport of sugars by rat small intestine, in-vitro. Biochem. Biophys. Res. Commun. 4:436440.

28. Schedl, H. P., and H. D. Wilson. 1971. Effects of diabetes on intestinal growth in the rat. J. Exp. Zool. 176:487-496.

29. Lal, D., and H. P. Schedl. 1974. Intestinal adaptation in diabetes: amino acid absorption. Am. J. Physiol. 227(4):827-831.

30. Caspary, W. F. 1973. Increase of active transport of conjugated bile salts in streptozocin-diabetic rat small intestine. Gut. 14:949-955.

31. Muller, F., K. Beyreiss, and H. Hartenstein. 1967. The effect of alloxan diabetes on the active absorption of monosaccharides. Acta Biol. Med. Ger. 19:673-681.

32. Fedorak, R. N., M. D. Gershon, and M. Field. 1989. Induction of intestinal glucose carriers in streptozocin-treated chronically diabetic rats. Gastroenterology. 96:37-44.

33. Cortas, N., and M. Walser. 1971. Na,K-ATPase in isolated mucosal cells of toad bladder. Biochim. Biophys. Acta. 249:993-995.

34. Cortas, N., D. Elstein, D. Markowitz, and I. S. Edelman. 1991. Anomalous mobilities of Na,K-ATPase $\alpha$ subunit isoforms in SDS-PAGE: identification by N-terminal sequencing. Biochim. Biophy. Acta. 1070:223-228.

35. Baginski, Z. S., P. P. Foa, and B. Zak. 1967. Microdetermination of inorganic phosphate, phospholipids, and total, phosphate in biological materials. Clin. Chem. 13:326-332.

36. Hubscher, G., and G. R. West. 1965. Specific assays of some phosphatases in subcellular fractions of small intestinal mucosa. Nature (Lond.). 205:799-800.

37. Gick, G. G., F. Ismael-Beigi, and I. S. Edelman. 1988. Thyroidal regulation of rat renal and hepatic Na,K-ATPase gene expression. J. Biol. Chem. 263:16610-16618.

38. Giles, K. W., and A. Meyers. 1965. An improved diphenylamine method for the estimation of deoxyribonucleic acid. Nature (Lond.). 206:93.

39. Maniatis, T., E. F. Fritsch, and J. Sambrook. 1988. Molecular cloning. A laboratory manual. Cold Spring Laboratory PressScenbrook, 2nd ed. Cold Spring Harbor Laboratory Press, Cold Spring Harbor, NY. 360-364.

40. Lowry, O. H., N. J. Rosebrough, A. L. Farr, and R. J. Randall. 1951. Protein measurement with the Folin phenol reagent. J. Biol. Chem. 193:265275.

41. Askari, A., W. Huang, and P. W. McCormick. 1983. $\left(\mathrm{Na}^{++} \mathrm{K}^{+}\right)$-dependent adenosine triphosphatase. Regulation of inorganic phosphate, magnesium ion, and calcium ion interactions with the enzyme by ouabain. J. Biol. Chem. 258:3453-3460.

42. Resh, M. D. 1982. Quantitation and characterization of the $\left(\mathrm{Na}^{+}, \mathrm{K}^{+}\right)$-adenosine triphosphatase in the rat adipocyte plasma membrane. $J$. Biol. Chem. 257:11946-11952.

43. Jorgenson, P. L. 1974. Purification and Characterization of $\left(\mathrm{Na}^{+}-\mathrm{K}^{+}\right)$-ATPase III Purification from the outer medulla of mammalian kidney after selective removal of membrane components by sodium dodecylsulfate. Biochim. Biophys. Acta. 356:36-52.

44. Chirgwin, J. M., A. E. Przybyla, R. J. Macdonald, and W. J. 1979. Rutter Isolation of biologically active ribonucleic acid from sources rich in ribonuclease. Biochemistry. 18:5294-5299.

45. Russo, J. J., M. A. Manuli, F. Ismail-Beigi, K. J. Sweadner, and I. S. Edelman. $1990 . \mathrm{Na}^{+}-\mathrm{K}^{+}$-ATPase in adipocyte differentiation in culture. Am. $J$. Physiol. 259:C968-C977.

46. Laemlii, U. K. 1970. Cleavage of structural proteins during the assembly 
of the head of bacteriophage T4. Nature (Lond.). 227:690-685.

47. Mogensen, C. E., M. W. Steffes, and J. S. Christiansen. 1981. Functional and morphological renal manifestations in diabetes mellitus. Diabetologia. 21:89-93.

48. Unger, R. H. 1971. Glucagon and the insulin: glucagon ration in diabetes and other catabolic illnesses. Diabetes. 20:834-838.

49. Unger, R. H., and L. Orci. Glucagon and the A cell. N. Eng. J. Med. 304:1518-1524, 1575-1580.

50. Khadouri, C., C. Barlet-Bas, and A. Doucet. 1987. Mechanism of increased tubular Na-K-ATPase during streptozocin-induced diabetes. Pflugers. Arch. 409:296-301.

51. Fein, F. S., L. B. Kornstein, J. E. Strobeck, J. M. Capasso, and E. H. Sonnenblick. 1980. Altered myocardial mechanics in diabetic rats. Circ. Res. 47:922-933.

52. Lytton, J., J. C. Lin, and G. Guidotti. 1985. Identification of two molecular forms of $\left(\mathrm{Na}^{+}, \mathrm{K}^{+}\right)$-ATPase in rat adipocytes. Relation to insulin stimulation of the enzyme. J. Biol. Chem. 260(2):1177-1184.

53. Liberman, U. A., Y. Asano, C. S. Lo, and I. S. Edelman. 1979. Relationship between $\mathrm{Na}^{+}$-dependent respiration and $\mathrm{Na}^{+}+\mathrm{K}^{+}$-adenosine triphosphatase activity in the action of thyroid hormone on rat jejunal mucosa. Biophys. $J$. 27:127-144.

54. Pressley, L., and J. W. Funder. 1975. Glucocorticoid and mineralocorticoid receptors in gut mucosa. Endocrinology. 97:588.

55. Lipkin, M. 1987. Proliferation and differentiation of normal and diseased gastrointestinal cells. In Physiology of the Gastrointestinal Tract, second edition. L. R. Johnson, editor. Raven Press, New York. 255-284.

56. Luppa, D., and F. Muller. 1986. Effect of diabetes and adrenocortical state on intestinal transport capacity and $\mathrm{Na}^{++} \mathrm{K}^{+}$activated adenosine triphosphatase activity. Diabete. \& Metab. 12:191-196.

57. Charney, A. N., and M. Donowitz. 1976. Prevention and reversal of cholera enterotoxin-induced intestinal secretion by methylprednisolone induction of $\mathrm{Na}^{+}-\mathrm{K}^{+}$-ATPase. J. Clin. Invest. 57:1590-1599.

58. Tai, Y. H., R. A. Decker, W. G. Marnane, A. N. Charney, and M. Dono- witz. 1981. Effects of methylprednisolone on electrolyte transport by in vitro rat ileum. Am. J. Physiol. 240:G365-G370.

59. McDonough, A., M. J. Tang, and L. Lescale-Matys. 1990. Ionic regulation of the biosynthesis of Na K-ATPase subunits. Seminars in Nephrology. 10:400409.

60. Fedorak, R. N., N. Cortas, and M. Field. 1991. Diabetes mellitus and glucagon alter ouabain-sensitive $\mathrm{Na}^{+}-\mathrm{K}^{+}$-ATPase in rat small intestine. Diabetes. 40:1603-1610.

61. Hartford, J. D., J. S. Skyler, and J. S. Barkin. 1990. Diabetes Mellitus, Theory and Practice, 4th ed. H. Rifkin and D. Porte, editors, Elsevier Science Publishing Co., Inc., New York. 824-837.

62. Chang, E. B., R. N. Fedorak, and M. Field. 1986. Experimental diabetic diarrhea in rats: Intestinal mucosal denervation hypersensitivity and treatment with clonidine. Gastroenterology. 91:564-569.

63. Vinnik, I. E., F. Kern, and K. E. Sussman. 1965. The effect of diabetes mellitus and insulin on glucose absorption by the small intestine in man. J. Lab. Clin. Med. 66:131-136.

64. Koch, K. S., and H. L. Leffert. 1979. Increased sodium ion influx is necessary to initiate rat hepatocyte proliferation. Cell. 18:153-163.

65. Smith, J. B., and E. Rozengurt. 1978. Serum stimulates the Na,K pump in quiescent fibroblasts by increasing $\mathrm{Na}^{+}$entry. Proc. Natl. Acad. Sci. USA. 75:5560-5564.

66. Kaplan, J. G. 1978. Membrane cation transport and the control of proliferation of mammalian cells. Annu. Rev. Physiol. 40:19-41.

67. Leffert, H. L., and K. S. Koch. 1980. Ionic events at the membrane initiate rat liver regeneration. Ann. NY Acad. Sci. 339:201-215.

68. Price, E. M., and J. B. Lingrel. 1988. Structure-function relationship in the $\mathrm{Na}, \mathrm{K}-\mathrm{ATPase} \alpha$ subunit: site-directed mutagenesis of glutamine-111 to arginine and asparagine- 122 to aspartic acid generates a ouabain-resistant enzyme. Biochemistry. 27:8400-8408.

69. Lu, X. P., and H. Leffert. 1991. Induction of sodium pump $\beta 1$-subunit mRNA expression during hepatocellular growth transitions in vitro and in vivo. J. Biol. Chem. 266:9276-9284. 